\title{
A Review of 'Humanitarian Intervention and Legitimacy Wars: Seeking Peace and Justice in the $21^{\text {st }}$ Century'
}

\author{
Published: 27 April 2015
}

Humanitarian Intervention and Legitimacy Wars: Seeking Peace and Justice in the $21^{\text {st }}$ Century Richard Falk

Routledge: New York, NY, USA. 2014

224 pp.; ISBN: 978-0-415-81553-6

In his book Humanitarian Intervention and Legitimacy Wars: Seeking Peace and Justice in the $21^{\text {st }}$ Century, Richard Falk argues that, with the growing prevalence of soft power, historical lessons of asymmetric warfare and legitimacy wars must be taken into account. Falk rejects the realist notion that the state is the only rational actor, offering a more constructivist approach that focuses on the norms, culture and morality of the international community. $\mathrm{He}$ asserts that humanitarian intervention is on the decline, and legitimacy wars are increasing. Much of this legitimacy is based on international law and its relevance in the international community.

Starting with the tribunals at the end of World War II, Falk seeks to demonstrate that geopolitics has created a double standard that prevents international law from being exercised evenly. After WWII, the only states that were subject to tribunals and punishments for war crimes were those states on the losing side. For example, the United States' use of nuclear weapons was overlooked, even though Falk sees this as a clear violation of international law. Falk finds this "top-down" approach to be ineffective because the norms of international law are not applied evenly.

In the future, Falk argues that legitimacy wars will make the push for humanitarian intervention. Soft power will overtake military prowess as the major player in international relations. Developed by Joseph Nye, soft power focuses on reaching desired outcomes without the use of coercion. One of the main differences of soft power is that it is not a trait exclusive to states; NGOs and international institutions can use soft power to influence other actors.

The use of soft power depends on people and civil societies to bring legitimacy to the struggle of a people against oppression of many kinds, putting international law and morality at the center of the struggle. He uses the issue of Palestine as an example. Many of the previous attempts at a solution have relied on the ineffective norms of international law, but the boycott, divestment and sanction (BDS) campaign of 2004 was far more successful. The BDS was created from the ground up by a coalition of NGOs. This has becomes a more successful, nonviolent way of pushing for Palestinian legitimacy and self-determination.

Falk's emphasis on issues of soft power is timely, given the current state of affairs. Ethnic groups like the Iraqi Kurds and the Palestinians are pushing for self-determination, basing many of their arguments on the human rights violations they have suffered and the basic need for their own state. All military action and violent activities are in pursuit of this one goal: to expand the rights of their people through any means necessary. He provides insight into this future direction of global conflict and provides a better understanding of where these conflicts will take place and how they will be won.

While Falk's theory is well developed, the early chapters do not provide sufficient definitions. The definition of "legitimacy war" seems lost. This makes the later examples of Palestine and Kosovo difficult to understand. What, exactly, makes these cases different from others like them? How does this relate to an understanding of soft power? The case studies in the later sections of the book are less impactful because the full definition of a "legitimacy war" is never fully given.

While there are some definitional pitfalls, Falk's book does provide a better map of what conflicts will look like in the future. He provides a better understanding of how soft power and civil society can have a role in conflicts. His case study of Palestine is particularly relevant, given the recent conflicts in the area. This book would be of interest to students of international law, human security, and international relations.

Leah Merchant

Department of Political Sciences, University of Cincinnati, Cincinnati, OH, USA; E-Mail: leahcmerchant@gmail.com 